\title{
Integration of local wisdom based on Naskah Amanat Galunggung in civics learning
}

\section{Integrasi nilai kearifan lokal berbasis Naskah Amanat Galunggung pada pembelajaran pendidikan kewarganegaraan}

\author{
Yepy Agus Ramdani \& Sapriya \\ Department of Civic Education FPIPS Universitas Pendidikan Indonesia \\ Jalan Setiabudi No. 229 Gd. FPIPS, UPI, Sukasari Bandung, \\ Jawa Barat 40154, Indonesia \\ E-mail: yepyagusramdanidn@gmail.com
}

\begin{abstract}
Indonesia as a developing country still faces with complex societal issues. To overcome these problems and to strengthen national identity one way is through the field of education. Education that takes into account the value of local wisdom will be easier to achieve educational goals. Naskah Amanat Galunggung contains the values of Sundanese wisdom that can be integrated into the Civic Education lesson. The location of the study was carried out on learning Civics in SMP Darul Falah 2 Cihampelas. The research method chosen is qualitative research using descriptive analytic method. In descriptive method of analytic data is collected as is then analyzed and given interpretation according to requirement of research. The results of this study indicates that the values contained in the Naskah Amanat Galunggung can be easily integrated into the Citizenship education as it is in accordance with the objectives of the Civic Education lesson. The integration of values of Amanat Galunggung in Civics Learning, especially in SMP Darul Falah 2 is by studying and inserting the local wisdom values in every Basic Competence.
\end{abstract}

Keywords: education, citizenship, values, wisdom, local

\begin{abstract}
Abstrak
Indonesia sebagai negara berkembang masih menghadapi persoalan-persoalan sosial kemasyarakatan yang kompleks. Untuk mengatasi permasalahan-permasalahan tersebut dan memperkuat identitas nasional salahsatu caranya adalah melalui bidang pendidikan. Pendidikan yang memperhatikan nilai kearifan lokal akan lebih mudah mencapai tujuan pendidikan. Naskah Amanat Galunggung memuat nilai-nilai kearifan Sunda yang dapat diintegrasikan ke dalam pelajaran Pendidikan Kewarganegaraan. Lokasi Penelitian dilaksanakan pada pembelajaran Pendidikan Kewarganegaraan di SMP Darul Falah 2 Cihampelas. Metode penelitian yang dipilih adalah penelitian kualitatif yang menggunakan metode deskriptif analitik. Dalam metode deskriptif analitik data dikumpulkan apa adanya kemudian dianalisis dan diberikan tafsiran sesuai dengan kebutuhan penelitian. Hasil penelitian ini menunjukkan bahwa nilai-nilai yang terdapat dalam Naskah Amanat Galunggung dapat diintegrasikan dengan mudah ke dalam pendidikan Kewarganegaraan karena sesuai dengan tujuan pelajaran Pendidikan Kewarganegaraan. Integrasi nilai Amanat Galunggung dalam pelajaran PKn, terutama di SMP Darul Falah 2 adalah dengan mempelajari dan menyertakan nilai kearifan local di tiap kompetensi dasar.
\end{abstract}

Kata kunci: pendidikan, kewarganegaraan, nilai, kearifan, lokal

\section{Introduction}

The national vision of the Republic of Indonesia, by virtue of the fourth paragraph of preamble of Constitution of the republic of Indonesia, is to protect the whole people of Indonesia and the entire homeland of Indonesia, to advance general prosperity, to develop the nation's intelligent life, and to contribute to the implementation of world order. These ideal vision shall be achieve in order to create just and prosperous country. There are many attempts taken by the people of Indonesia to 
realize the vision of this country. The goal of national development is raised in order to keep up with the competition in globalization era. Thus, it needs the advancement of human resource's quality to complete the national development.

At the moment, Indonesia is still facing complex social problems. The effects of globalization grow bigger since the Information and Communication Technology is growing more advanced in short time as if countries' border is no longer exist. This somehow sparks more social problems, such as separatism issues, social chaos, imbalance development, and the degradation of cultural and nationalism values among the youth. This is confirmed by Kartawinata (2011) that the strong influence of globalization can set the local cultural values aside, and replacing them with the foreign cultures as they are packaged in a tempting manner. This will happen both in cities and even in small villages.

The social problems mentioned above could drag Indonesia into its destruction. Regarding to the case, Lickona (1991) in Tasripin (2011) stated that the occurrence of moral degradation in a country is one of the indications of its destruction, for example: 1) the number of juvenile delinquency is increasing; 2) dishonesty outspreads as a culture among the society; 3 ) the lack of respect towards parents, teachers, and the figure of leaders; 4) peer group contributes to violence acts; 5) the increasing of distrust and hatred between the high and low class society; 6) bad use of language and words; 7) the working performance goes worse than the previous generation; 8) the people are lack of responsibility as a citizen; 9) the hype of self-destruction acts among the teenagers, such as drug abuse, alcohol, and free sex, dan 10) the increasing of ignorance towards moral values. In fact, all those indications have raised and emerged in Indonesia at the moment.

The diversity of tribes, language culture, and religion in Indonesia somehow speed up the cultural shift as more and more foreign cultures tried to penetrate and replace the set of values in Indonesia.

In order to overcome the problem above and strengthen the national identity, there are several strategies that can be implemented, that is through education. Therefore, education is the most important media to build the Indonesia that we dream of by enhancing the nation's intellectual life.

Gallagher (2011) stated his opinion about the role of education among a multicultural society as follows:

$$
\begin{aligned}
& \text { "The role of education in ethnically dividied societies has varied in time and place: } \\
& \text { sometimes education has been used as a tool of assimilation and denied the rights of minority } \\
& \text { to expression, in other contexts minorities enjoy the right to run their own schools, and in yet } \\
& \text { other contexts they are forced to attend inferior schools" (Gallagher 2011). }
\end{aligned}
$$

Educational policy will never work properly without being oriented to the culture of the society in the area. This factor is one of the influential instruments that should be considered about in order to ensure the success of the education. Local culture-based education is the strategy that could achieve the goal best since the culture mainly contribute to the life of society.

When we try to relate the culture to our current life, the values are still stays in their place among the society that they need to be preserved. However, we still need to analyze about the actualization further to match them to the needs of people in the era without removing the real essence of the culture since, as what the authors believe, the essence of culture contains the local wisdom of the country.

In counteracting the globalization occurred in Indonesia, the country urged to learn the good lessons from the developed countries and then adapt them to the local values (Surya 2011:3). Barely accepting foreign cultures without integrating them to the existing local wisdom could hinder our generation from learning about their root culture. We could witness that many start to undermine their own culture while praising the foreign culture, including in terms of education. This is caused by inferiority complex suffered by Indonesian as the result of colonialism by the Western countries for several decades (Alwasilah 2009). 
Within the preface of local wisdom book by Kartawinata (2011), it is stated that local wisdom contains many values about special explicit and implicit concept belongs to a particular person, group, or even society. Local wisdom is composed of fact, concept, belief, and perception of the society towards the environment where they live in/ come from. It includes of their way in observing and measuring the environment, solving problem, and validating information. "In short, local wisdom is the process how a knowledge is initiated, stored, implemented, processed, and inherited" (Alwasilah 2009).

Additionally, Civic Education should also be integrated to the local wisdom values in order to mold the national. Thus it would be easier to be directly implemented and in the daily life practices. Local wisdom values within the culture need to be studied and developed further to enrich the material of Civic Education.

Sunda, as the second largest tribes in Indonesia, plays a huge role in developing local wisdom-based education, especially for Civic Education. There are many more local wisdom values originated from Sunda tribes that needs to be examined, studied, and developed further since local wisdom is the essential part of society's life, including for Sunda people. Hermawan (2008) stated that "Sunda's local culture-based education is the important process in West Java educational system". One of the local wisdom sources that is still left untouched from the scholar is Naskah Amanat Galunggung or Mandate Galunggung Script. The script is written in Old Sundanese letter. It was initially discovered by the experts in di kabuyutan Ciburuy di Bayongbong, Garut, Jawa Barat. It is mentioned in the book titled Tiga Pesona Sunda Kuna (translated by Hawe Setiawan) Noordyn \& Teeuw (2009). Therefore, it is necessary to study about Naskah Amanat Galunggung as it is the legacy of Sundanese ancestors.

According to Suryalaga (2009), Prabuguru Darmasiksalah was a public figure who used to give many advices about the fundamental of life vision or life lessons that is written in Naskah Amanat Galunggung. Amanat Galunggung teaches about the morality lesson and social rules that must be obeyed by Sundanese people.

In general, this research aims to identify the local wisdom values contained in Amanat Galunggung that will be integrated to Civic Education learning. Schools have the obligation to develop character education oriented to Sundanese local wisdom to achieve Pancasila-based Sundanese character learning (Sukmayadi 2012). This character education is particularly provided in Civic Education.

Zuriah (2000), in her research findings emphasized that "the learning model using local wisdombased multicultural Civic Education could elevate the multicultural nationality competence of he college students in Higher Education". This will also work if applied in high school as studied in this research.

\section{Research Method}

The research took place in SMP Darul Falah 2 that is located in di Jalan Raya Cihampelas Kabupaten Bandung Barat. This study applied qualitative research, using analytic descriptive method. Qualitative research is generally used to human being along with their environment, their interaction with others, their language and also their perception upon their surrounding environment (Nasution 1996).

The techniques implemented in this research are: documentation, observation, and interview. Most of the facts and data are stored in the form of documentation. Most data obtained are in the form of letters, daily notes, souvenir, report, artifact, pictures, document, etc. Such data is not limited to space and time that it allows researchers to discover many new events in the past. In details, documenter material is categorized into several types, such as autobiography, personal letters, books or daily notes, memorial, clipping, legal or private document, data in server or flashdisk, data from websites, etc.

Documents are note of events happened in the past. It can be in the form of written document, pictures, or monumental masterpieces from someone, as mentioned by Sugiyono (2007). 
The main source in this research is the document of Translated Original Script of Amanat Galunggung by Drs. Atja and Drs. Saleh Danasasmita.

Some information obtained during the observation is the location (space), subject, activity, object, action, event, time, and emotion. Observation was conducted to present the realistic portrayal of an action or event to answer a question, understand human's behavior, and to evaluate (to measure several aspects and to give feedback upon the aspects).

Ratcliff (2001:75) explained that there are several means of observation that can be implemented in qualitative research, those are participation observation, unstructured observation, and group observation.

Interview is an instrument that helps to proof or support the information obtained by the researcher. The technique of interview implemented in the study is in-depth interview. Indepth interview is the process to gain information, for the sake of the study, by conducting question and answer session face to face, between the interviewer and the informant or the interviewee. The researcher may choose whether to use interview guide when both parties has involved in a social environment in a long period of time.

After all the data has been collected through documentation, observation, and interview, all the data will be analyzed and examined. Later, the data is summarized to focus on the important aspects regarding to the research problems. It is suitable to what Nasution (1996:29) stated that all the reports gained should be selected and focused on the main and important aspect to determine the topic or the pattern. So, it will be resulted into a summarized raw report that is systematically structured and easy to understand.

When the data has been collected, summarized, and matched to the focus of the research, it will be analyzed and tested the realiability using the several techniques mentioned by Nasution (1996:129). Those are data reduction, data display, and conclusion making or verification as the general steps in analyzing and examining the reliability of the data collected. There are many choices of technique can be used since there is no one certain technique applicable for all kinds of research.

\section{Result and Discussion}

In order to describe whether the content of Naskah Amanat Galunggung can be integrated to Civic Education, we need to identify the objective and the scope of Civic Education. The objective of this subject in accordance with Constitution of the Republic of Indonesia Number 20 year 2003 about National Education System in elucidation section of Article 37 Clause (1) that "Civic education aims to shape the learners to be human being with pride upon their nation and country".

The goals of civic education mainly focus on the feeling of pride towards the nation and country. It is suitable with the content of Naskah Amanat Galunggung which mentioned and taught about the obligation for all citizens to maintain the sovereignity of the country (kabuyutan) from the opponent's attack. This proves that the prideupon the nation and country is part of the focus of interest in Naskah Amanat Galunggung, as it is mentioned by Andrita as follows:

"Be cautious to the time when the power dan glory will be taken by Sunda, Jawa, Lampung, Baluk, traders (foreigner), and other who attempt to take over kabuyutan in Galunggung............. When a war to fight over kabuyutan in Galunggung rise, go to kebuyutan and defend it. Is there anything harder to defend and fixed in Galunggung? Never let Javanese, Baluk, China, Lampung, and other tribes take over kabuyutan. Really a civet's skin in the trash is more valuable than the land (kabuyutan) which taken over by other people" (Andritra 2014).

In Naskah Amanat Galunggung, the scope of civic education and character education material is also included in the teaching of naskah Amanat Galunggung. Based on the translated version of Naskah Amanat Galunggung, the researchers divide the summary framework into four major 
points (Suryalaga 2002): life lesson mandate/cecekelan hirup, negative attitude mandate (nonethical) that is indicated by the word "ulah" that means "do not", positive attitude mandate (ethical) indicated by the word "kudu" which means "must", and several other values.

The summary of Naskah Amanat Galunggung is relevant to the scope of civic education and character education as Civic education is a multi-dimensional learning that includes value learning, moral learning, and norms learning aside of other materials like character education, constitution, politics, and law.

The concept applied in teaching and learning process, particularly in civic education, can be obtained from the concept of the field or other concept that generally used in the students' environment and the surrounding society.

In Civic Education, there are several basic concepts that is mostly used as shown in Table 1.:

Table 1 .

Basic concept of civic education

\begin{tabular}{ll}
\hline Government & Authority \\
Country & People Power \\
Nation & Ruling Class \\
Country & Pressure Group \\
Region & Nationalism \\
Development & Moral \\
Developed Country & Behavior \\
Developing Country & Moral action \\
Under-developed Country & Conscience \\
Decision Making & Empathy \\
Moral & Power \\
Value & Authority \\
Character & Politic \\
Feeling & Politic Party \\
Attitude & Election \\
Solidarity & Constitution \\
\hline
\end{tabular}

Source: Sapriya (2012)

As it is mentioned above, Civic Education have basic concepts. Similarly, Naskah amanat Galunggung also have its own basic concepts. There are several basic concepts in Naskah Amanat Galungglung (Atja \& Saleh 1981) that is similar to which belongs to Civic Education. The basic concepts of Naskah Amanat Galunggung is summarized in Table 2.

There are many values and advices for the society inside Naskah Amanat Galunggung. It contains guidance and warning for the society and also government to help the leader to govern the area in order to achieve prosperity.

The local wisdoms stated in Naskah Amanat Galunggung are mainly in the form of suggestion and prohibition from Prabuguru Darmasiksa for his son, Sang Lumahing Taman, along with all his descendants. But through examining the content, the values inside it is still relevant to the life of people in this country and in this moment. 
Table 2.

Basic concept of Naskah Amanat Galunggung

\begin{tabular}{ll}
\hline Unity & Moral Value \\
Government & Self-control \\
Kabuyutan (Country) & Ethics \\
Nation & Affluence \\
Country & Prosperity \\
Region & Responsibility \\
Tolerance & Position \\
Honesty & Government \\
Truth & Religiousness \\
Benevolence & Sincerity \\
Power & Bravery \\
Nationalism & Discipline \\
Defense and security & Ruler \\
State Nurture Attempts & Authority \\
Value & Politics \\
Character & Nobility \\
Feeling & Skill \\
Attitude & Intelligence \\
Behavior & Dexterity \\
\hline Source: Data processing result &
\end{tabular}

Among all the concepts within Naskah Amanat Galunggung, the most similar concepts to those in Civic Educations and also the translated version of Naskah Amanat Galunggung are summarized in table 3 (Atja \& Saleh 1981):

Table 3.

Basic concepts in Naskah Amanat Galunggung and translated text of Naskah Amanat Galunggung

\begin{tabular}{|c|c|}
\hline $\begin{array}{l}\text { Basic Concept of Naskah Amanat } \\
\text { Galunggung }\end{array}$ & $\begin{array}{l}\text { Translated Version of Naskah Amanat } \\
\text { Galunggung }\end{array}$ \\
\hline Unity & $\begin{array}{l}\text { Do not fight merely because of argument, do not } \\
\text { be violent to others; be nice and gentle instead }\end{array}$ \\
\hline Government & $\begin{array}{l}\text { Governance matters are the responsibility of the } \\
\text { leader }\end{array}$ \\
\hline Kabuyutan (Country/ Hometown) & $\begin{array}{l}\text { The words "I verso" is mentioned several times } \\
\text { in several parts }\end{array}$ \\
\hline Nation & Sunda, Jawa, Lampung, Baluk, trader (foreigner) \\
\hline Country & $\begin{array}{l}\text {.... opponent from land and sea, from west and } \\
\text { east around the country }\end{array}$ \\
\hline Region & $\begin{array}{l}\text { In terms of geographic border, it is not explained } \\
\text { clearly and explicitly. But it mentioned about } \\
\text { the existence of other region/area aside of } \\
\text { kabuyutan (country) area of Galunggung in a } \\
\text { non explicit manner. }\end{array}$ \\
\hline Citizen & ..... between one and another \\
\hline Tolerance & $\begin{array}{l}\text { Do not fight merely because of argument, do not } \\
\text { be violent to others }\end{array}$ \\
\hline Power & $\begin{array}{l}\text { Be cautious to the time when the power ....... will } \\
\text { be taken }\end{array}$ \\
\hline
\end{tabular}




\begin{tabular}{|c|c|}
\hline Nationalism & $\begin{array}{l}\text { Be cautious to the time when the power dan } \\
\text { glory will be taken by Sunda, Jawa, Lampung, } \\
\text { Baluk, traders (foreigner), and other who attempt } \\
\text { to take over kabuyutan in Galunggung }\end{array}$ \\
\hline Safety and Security & $\begin{array}{l}\text { When a war to fight over kabuyutan in } \\
\text { Galunggung rise, go to bebuyutan and defend it. } \\
\text { Is there anything harder to defend and fixed in } \\
\text { Galunggung? }\end{array}$ \\
\hline State Nurture Attempt & $\begin{array}{l}\text { Never let Javanese, Baluk, China, Lampung, } \\
\text { and other tribes take over kabuyutan. Really a } \\
\text { civet's skin in the trash is more valuable than } \\
\text { the land (kabuyutan) which taken over by other } \\
\text { people. }\end{array}$ \\
\hline $\begin{array}{l}\text { Morality; Value; Character; Behavior; } \\
\text { Attitude; Ethic }\end{array}$ & $\begin{array}{l}\text { Below is the example of concept about Morality, } \\
\text { values, Character, Attitude, Behavior, and ethics } \\
\text { from several statements in the script: } \\
\text { Never intentionally fight over something: be } \\
\text { righteous. Be benevolent, honest, and pure. } \\
\text { Do not marry your siblings, hurt and kill the } \\
\text { innocents, suspicious towards your spouse, and } \\
\text { suspicious towards one and another }\end{array}$ \\
\hline Position & Do not fight over a position....." \\
\hline Government & $\begin{array}{l}\text { Governance matter is the responsibility of the } \\
\text { leader (prabu/ King) }\end{array}$ \\
\hline Discipline & $\begin{array}{l}\text { The words indiscipline mentioned in part IV } \\
\text { verso }\end{array}$ \\
\hline Ruler & $\begin{array}{l}\text { Respect the noble people, either the landlord, } \\
\text { the leader, priest/ religious leaders, and the } \\
\text { leaders/king around the world. Be aware of } \\
\text { karma and obey your leader. Never ignore what } \\
\text { your leader says. }\end{array}$ \\
\hline Authority & $\begin{array}{l}\text { Though it is not mentioned explicitly, but the } \\
\text { statement of "this is the initial warning from, that } \\
\text { is when he built a trench to defend Pakuan" } \\
\text { shows that the concept of authority is also } \\
\text { captured in Naskah Amanat Galunggung". }\end{array}$ \\
\hline Politic & $\begin{array}{l}\text { Though it is not mentioned explicitly, but the } \\
\text { statement of "Keep it that you will be respected } \\
\text { by the people and make the country save and } \\
\text { secure, prosperous, and powerful. Listen to what } \\
\text { parents' said, defends your country and win the } \\
\text { war, grow plants, keep the glory, and follow the } \\
\text { values inherited by the ancestors. For the sake } \\
\text { of prosperity and the continuity of government, } \\
\text { do not fight over position, money, rewards as } \\
\text { all have the same respect and originated from } \\
\text { the same source." This statement shows that } \\
\text { there is politic concept inside Naskah Amanat } \\
\text { Galunggung. }\end{array}$ \\
\hline
\end{tabular}

Source: Data Processing Result 
Table 4 .

Values taught in Naskah Amanat Galunggung

\begin{tabular}{|c|c|}
\hline Advices & Prohibition \\
\hline Be unit & Do not fight \\
\hline Do not ignore the prohibition set for you & Do not be rude to others \\
\hline Listen to your parent's advice & Do not only Focus on Your Ambitioni \\
\hline Harus Mengindahkan Ajaran Patikrama & Do not Marry Your Siblings \\
\hline (Moral) & Do not Kill the Innocents \\
\hline Be Religious & Do not seize belongings of the innocent \\
\hline Be Righteous & Do not Hurt the Innocents \\
\hline Be Generous & Do not Accuse the Innocents \\
\hline Smile & Do not be Suspicious to one another \\
\hline Be Lively & Do not be Hesitant in Facing the Opponent \\
\hline Speak convincingly & Do not Ignore your Ancestor's Rules \\
\hline Be affectionate to other human beings & Do not Fight Over Position \\
\hline Be adept & Do not Fight Over Money \\
\hline Be Skillfull & Do not Fight over Rewards \\
\hline Be Sincere & Do not Shout when Speak \\
\hline Work hard & Do not Tease People \\
\hline Be Tawakkal & Do not Insult Others \\
\hline Keep your Spirit & Do not Make up Stories \\
\hline Be Brave to Stand on Justice & Do not be Lazy \\
\hline Be Attentive & Do not be Stubborn \\
\hline Be careful & Do not be Naive \\
\hline Be diligent & Do not be Gloomy \\
\hline Be consistent & Do not be Shy \\
\hline Set your Priority Right & Do not get Offended Easily \\
\hline Keep Your Spirit & Do not be Slow \\
\hline Be Discipline & Do not Sleep all the time \\
\hline Be Courageous & Do not be Careless \\
\hline \multirow[t]{2}{*}{ Be serious } & Do not be Forgetful \\
\hline & Do not be Disputant \\
\hline Be trustworthy, & Do not Tell a Lie \\
\hline Love your Parents & Do not Grumble \\
\hline Be careful in Selecting a Wife & Do not be bored \\
\hline Be careful in Selecting a Spouse & Do not be Afraid to Give in \\
\hline Be careful in Recruiting a Member & Do not be too Ambitious \\
\hline Ask to Your Parents & Do not get Influenced Easily \\
\hline $\begin{array}{l}\text { Be Productive } \\
\text { Be afraid of Sins }\end{array}$ & $\begin{array}{l}\text { Do not Trust People for Granted (without investi- } \\
\text { gating first) }\end{array}$ \\
\hline Respect Noble Person & Do not get frowned easily \\
\hline Appreciate Beauty & Do not be Annoying \\
\hline \multirow[t]{8}{*}{ Focus on Your Dream } & Do not Create Scandal \\
\hline & Do not have low Character \\
\hline & Do not Get Influenced easily \\
\hline & Do not Do Anything that Hinder our Good Deeds \\
\hline & Do not listen to Bad Words \\
\hline & Do not get Disappointed Easily \\
\hline & Do not be Conceited \\
\hline & Do not Complain Every time \\
\hline
\end{tabular}

Source: Data Processing Result

From explanation in Table 4. it is apparent that that Naskah Amanat Galunggung has a rich content that has to be learnt by the society as well as the government in order to achieve a 
secure, prosperous, and glorious country.

According to the scope of Civics Learning, we know that Civics learning contains some materials like values, norms, law and regulation that rule the attitude of the society. Therefore, it is expected that the students could actualize the material in their daily basis and take them as the part of their character. The content of Naskah Amanat Galunggung really support and suitable to the scope of learning in Civics Education. This is because Naskah Amanat Galunggung contains many similar values to those in Civics Education.

Table 5.

Scope of learning in civics education and the suitable values in Naskah Amanat Galunggung

\begin{tabular}{ll}
\hline Scope of Learning in Civic Education & Basic Concept of naskah Amanat Galunggung \\
\hline Unity of the Nation & Unity and Tolerance \\
Norms, Law, and Regulation & Discipline \\
Human Rights & Citizen, Nationalism \\
Citizen Needs & State Nurture, Region \\
Country's Constitution & Safety and Security, Position, \\
Power and Politics & Government, Ruler \\
Pancasila & Power, Authority, Politic, Ethics, Moral \\
Globalization & Values, Character, Attitude, Nation \\
\hline
\end{tabular}

Source: Data Processing Result

After we analyzed the similarity and suitability between the scope of learning in Civics Education and the basic concept of Naskah Amanat Galunggung, the next question would be how to integrate the content material of Naskah Amanat Galunggung to the Curriculum of Civics Education. Wagiran (2011) explained that schools usually integrate the local wisdom values into the local content subject in the curriculum, there are several types of local content: 1. Single Subject Model Local Content 2. Integrative Model Local Content (Integratif) 3. Discreet Local Content.

The research shows that the easiest and most applicable model of local content to be conducted in order to integrate the local wisdom of Naskah Amanat Galunggung to the curriculum structure of Civics Education in di SMP Darul Falah 2 Cihampelas is Single Subject Model. This is because Single Subject model is not too complicated for schools which is currently introduce local wisdoms of Naskah Amanat Galunggung, as it only needs to be integrated to the curriculum by inserting them in the formulation of Lesson Plan in accordance with the standard of content and the standard of process mentioned in the Syllabus.

\section{Conclusion}

Based on the comparison among the basic concept and the value inside Naskah Amanat Galunggung, scope of learning in Civics Education, the values are suitable to the scope of learning. Thus, it can be integrated to the Civics learning. The integration of values of Amanat Galunggung in Civics Learning, especially in SMP Darul Falah 2 is by studying and inserting the local wisdom values in every Basic Competence.

The success of Naskah Amanat Galunggung values integration to Civis Learning is not enough to stop only in the study stage and inserting the values to the Basic Competences in the syllabus of Civics Learning, but also in the moment the material is being taught and how the local wisdom is being delivered during the learning. In order to assure the success, a good delivery strategy that is adjusted to the condition in the field is needed knowing there are several obstacles that have to be aware of in integrating the local wisdom, those obstacle are the students' low understanding towards local wisdom and the low ability of the teacher in transforming the local wisdom to a worthteaching material. 


\section{References}

Alwasilah AC (2009) Pokoknya Kualitatif (Dasar-dasar Merancang dan Melakukan Penelitian Kualitatif). Jakarta: Pustaka Jaya.

Atja \& Saleh D (1981) Amanat dari Galunggung (Kropak 632 dari Kabuyutan Ciburuy, BayongbongGarut). Bandung: Proyek Pengembangan Permuseuman Jawa Barat [Accessed 16 Juni 2017]. http://bumisangkala.blogspot.co.id/2012/06/naskah-amanat-dari-galunggung.html.

Andritra YG (2014) Orang Asing dalam Naskah Amanat Galunggung. Membaca, Menulis, dan Diskusi:Blog [Ascessed 16 Juni 2017]. http://www.lpik.org/linguistik/orang-asing-dalamnaskah-amanat-galunggung.

Gallagher T (2011) Conflict, education and ethnicity-dealing with division and cohesion through education. C \& E Conflict and Education - An Inter Displinary Journal 1 (1):1-4.

Hermawan I (2008) Kearifan Lokal Sunda dalam Pendidikan (Kajian Terhadap Akulturasi NilaiNilai Tradisi Sunda dalam Pendidikan IPS di Sekolah dan Yayasan Atikan Sunda). Bandung: Universitas Pendidikan Indonesia.

Kartawinata AM (2011) Buku Kearifan Lokal Di Tengah Modernisasi. Jakarta: Kementerian Kebudayaan dan Pariwisata Republik Indonesia.

Lickona T (1991) Educating for Character: How Our Schools Can Teach Respect and Responsibility. New York: Bantam Books.

Nasution S (1996) Metode Penelitian Kualitatif Naturalistik. Jakarta: Sinar Grafika.

Noordyn J \& A Teeuw (2009) Tiga Pesona Sunda Kuna (Terjemahan oleh Hawe Setiawan). Jakarta: Pustaka Jaya.

Ratcliff D (2008) Qualitative data analysis and the transforming moment. Common Ground Journal 5 (2):160-181.

Sapriya (2012) Konsep Dasar Pendidikan Kewarganegaraan [PKn]. Jakarta: Direktorat Jenderal Pendidikan Islam Kementerian Agama Republik Indonesia.

Sugiyono (2007) Metode Penelitian Kuantitatif Kualitatif dan R \& D. Bandung: Alfabeta.

Surya P (2011) Kepemimpinan Etnopedagogi di Sekolah. Yogyakarta: UNY.

Suryalaga H (2002) Amanat Galunggung Prabuguru Darmasiksa Luluhur Sunda. [Accessed 16 Juni 2017]. http://www.sundanet.com/article/content/117.

Suryalaga H (2009) Kasundaan Rawayan Jati. Bandung: Yayasan Nur Hidayah.

Tasripin (2011) Pengembangan Pendidikan Karakter Melalui Kegiatan Ekstrakurikuler Berbasis Pembiasaan. Studi Kasus di SDN Sukarame 01 Kecamatan Caringin Kabupaten Garut. Tesis, Universitas Pendidikan Indonesia, Bandung.

Wagiran (2011) Pengembangan model pendidikan kearifan lokal dalam mendukung visi pembangunan Provinsi Daerah Istimewa Yogyakarta 2020 (Tahun Kedua). Jurnal Penelitian dan Pengembangan, III (3):85-100. 